[Vicino Oriente XIX (2015), pp. 25-37]

\title{
PARALLEL PASSAGES AMONG HITTITE-LUWIAN RITUALS: FOR THE RESTORATION OF KUB 35.146*
}

\author{
Valerio Pisaniello - Sapienza Università di Roma
}

This paper presents the restoration of KUB 35.146, a MS Hittite-Luwian ritual fragment which has several passages running parallel to paragraphs of other ritual texts. Such a topic gives us an opportunity to make some observations about how Hittite ritual texts were composed.

Keywords: Hittite; Luwian; rituals; philology; parallel passages

A broken section of the Hittite-Luwian ritual fragment KUB 35.146 (MS, CTH 767.3), ${ }^{1}$ containing a conjuring formula, runs parallel to a passage of the Hittite ritual fragment $\mathrm{KBo}$ 20.73+ (OH or MH/MS, CTH 458.1.1.A). These two texts, both found in Room 5 of Building A on the Büyükkale, are sometimes cited together in the literature, because they share some particular forms, but no one seems to have noticed that this is not due to chance. Here follow the two texts (and the translation of the second one):

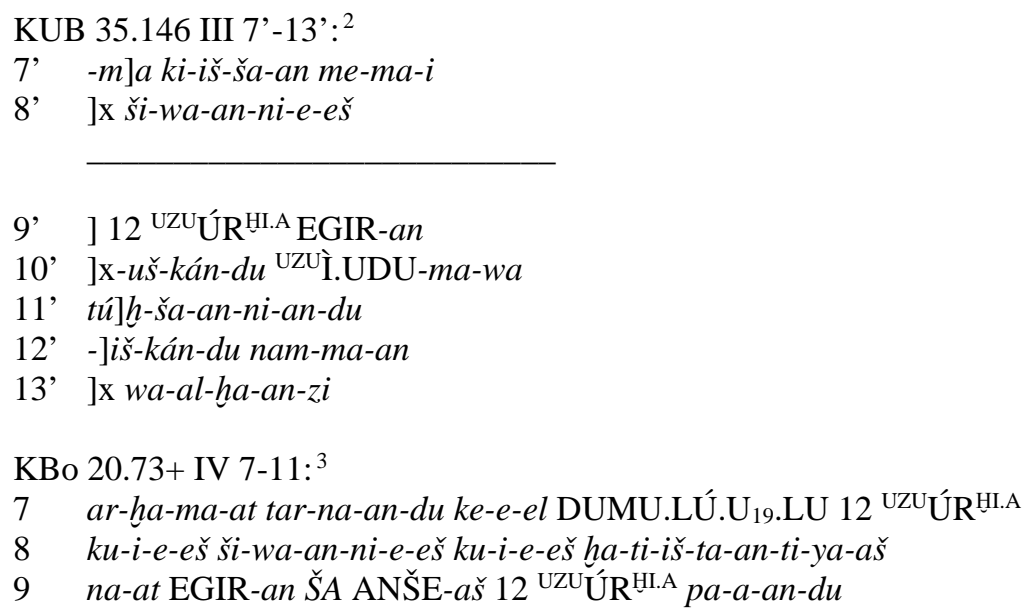

10 nu e-eš-ḩar ak-ku-uš-kán-du UZÙ̀.UDU $a^{!}-a z-z a-k u-w a-a n-d u$ UZUSA-ma 11 túh-ša-an-ni-ya-an-du ha-aš-ta-i-ma du-wa-ar-ni-iš-kán-du

\footnotetext{
I would like to thank Rita Francia, who encouraged and supported me, and has also given me precious advices.

1 Abbreviations are those of H.G. Güterbock - H.A. Hoffner, The Hittite Dictionary of the Oriental Institute of the University of Chicago. L-N, Chicago 1989, XV-XXVIII.

2 Starke 1985, 269.

3 Fuscagni 2013.
} 
«They (i.e. the diseases) shall relase them, (i.e.) the twelve body parts of this human being, those which are of divine origin (and) those which are caused by witchcraft, ${ }^{4}$ and they shall follow the twelve body parts of the donkey! They shall keep drinking the blood (of the donkey), they shall keep eating (its) fat, they shall keep cutting off (its) sinew and they shall keep breaking (its) bone!».

The remaining parts of the preserved texts clearly point at two different compositions, though there are some elements in common (see below). KBo 20.73+ has several passages running parallel to paragraphs of the rituals ascribed to the "old woman” Tunnawiya (CTH 409 and CTH 760 $)^{5}$ and it has been labeled as a conjuring ritual with mythological narrative, since in I 3'-6' there is a small passage concerning the Solar deity, who is asked to release the "lord of the ritual" from a variety of diseases listed in 1l. 9'-16'. Then the text becomes quite obscure, due to breaks: we meet again the Solar deity, now with the Ilaliyant-deities (ll. 21'-22'), and then several actions are described, which take place on a road and involve the god Antaliya, the river Maraššanta and a black bull (ll. 26'-31'). At the beginning of column IV we find again some diseases listed (ll. 1-4) and finally the substitution ritual by which these are transferred from the "lord of the ritual" to a donkey. Here is the formula cited above, which forces the negative entities to affect the donkey releasing the man. Then actions with the donkey are performed and, at the end, the "old woman" spells a formula of analogical magic and performs other ritual actions.

KUB 35.146 is instead a very fragmentary ritual with Luwian words ${ }^{6}$ and some scholars noticed some similarities with the ritual of Tunnawiya. ${ }^{7}$ In the second column, after two very fragmentary paragraphs, the text lists the materia magica for the ritual, including some kinds of bread, fruits and other substances with Luwian names. The next two paragraphs contain the conjuring formula, which exhorts the evil forces to take the substances listed before. ${ }^{8}$ There are some other fragmentary lines and then the tablet breaks. The third column, also broken, starts with a series of negative things, but we don't know what exactly happens to them, since the verb is always replaced by KI.MIN 'ditto'. Then, after some fragmentary lines, we have the passage quoted above, with an introduction in l. 7' (kiššan memai) and the conjuring formula in ll. 8'-12', followed by another line before the paragraph. Then there is another direct speech in ll. 14'-20', unfortunately too fragmentary and with some unclear Luwian verbs, and then the preserved text ends.

The analogies between these two MH script compositions and the rituals of the "old woman” Tunnawiya, as well as the presence of Luwian words, point at a Kizzuwatnean

4 This meaning of the word hateštant- is likely but uncertain and the etymology is far from assured (cf. HED H, 265); I follow here HW² I, 506 and Fuscagni 2013.

5 For a list of the correspondences, cf. the introduction of the edition of KBo 20.73+ on the Hethitologie Portal Mainz (Fuscagni 2013). As Francesco Fuscagni suggests, this composition could also belong to the ritual of Tunnawiya and it could be one of the missing tablets of CTH 409 or CTH 760.

6 See the Appendix below for the full text.

7 Cf. Laroche 1954, 122, who states «conjuration qui rappelle un peu le Tunnawi», since he reads the same objects in KUB 35.146 II 6'-9' and in KUB 12.58+ I 46-47. As will be shown below, this is not the only affinity. It is obviously possible that this composition was part of the rituals of Tunnawiya, but the preserved text is too short to state it positively.

8 See the Appendix below and Haas 2003, 129, n. 563. 
Luwian background, ${ }^{9}$ so it is not surprising that there could be similarities between the two texts, and indeed, despite the differences, KBo 20.73+ IV 9-11 resembles almost perfectly ll. 9'-12' of KUB 35.146 III, which can be accordingly restored as follows:

7' $\quad[\ldots-m] a$ ki-iš-ša-an me-ma-i

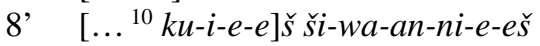

9' $\quad\left[\ldots{ }^{11}\right.$ na-at ŠA ANŠE-aš $] 12$ UZU ÚR RII.A EGIR-an

10, [pa-a-an-du nu e-eš-har ak-k]u-uš-kán-du UZÙ̇.UDU-ma-wa

11' [a-az-za-ku-wa-an-du UZUSA-ma tú] $h$-ša-an-ni-an-du

12' [ha-aš-ta-i-ma du-wa-ar-ni-]iš-kán-du nam-ma-an

13' [...]x wa-al-ha-an-zi

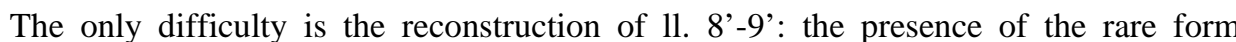
šiwanna/ $i^{-12}$ in both texts is a strong hint of parallelism, ${ }^{13}$ but the formula clearly begins in l. 8' and the space available in the break doesn't seem large enough to restore all the elements which are in KBo 20.73+ IV 7-8. Possibly ll. 8'-9' contained a somehow shortened similar formula.

Ascertained the parallel between the two texts, we can now turn to ll. 5'-6' of KUB $35.146 \mathrm{III}$ and see if it's possible to understand them with the help of KBo 20.73+:

\section{5' [...]x-iz-zi na-an-kán a-ra-ah-za-an-da \\ 6' [...] 9 KASKAL $^{N I}$-ma-kán pa-ra-a}

These lines do not share anything with the section of KBo 20.73+ preceeding the one cited above, but, curiously, we can compare them with the lines immediately following the conjuring formula:

KBo 20.73+ IV 12-13:

12 'na-an`-kán a-ra-ah-za-an-da 3-ŠU wa-ah-nu-wa-an-zi I-NA 4 KASKAL-ma-an

9 I am using here the label "Kizzuwatnean Luwian ritual” in its broadest meaning. Contra Miller 2004, 458. Melchert 2013, 168 convincingly argues that the ritual of Tunnawiya (CTH 409) shows the Kizzuwatna dialect, concluding: «the label "Kizzuwatna" cannot sensibly be applied only to rituals that show a mixture of Hurrian and Luvian elements. Nor is the distinction between the two types of rituals [i.e. Kizzuwatna rituals with Hurrian elements and rituals with Kizzuwatna Luwian incantations without Hurrian] an absolute one».

10 Maybe we can follow KBo 20.73+ IV 7 and restore here something like ar-ha-ma-at tar-na-an-du (but arh $a=m a=a t$ could hardly be at the beginning of a direct speech): ar-ha-wa-ar-at tar-na-an-du could be a solution, but I think there is not enough space for it.

11 Not enough space available for ku-i-e-eš ha-ti-iš-ta-an-ti-ya-aš if we restore na-at ŠA ANŠE-aš, which seems necessary to me. We could think there was something equivalent, despite the paragraph, but the space available is few.

12 On this word cf. Rieken 1999, 37 n. 160 and CHD Š/3, 488.

13 In addition, the broken sign preceding the word šiwanna/i- is probably EŠ, so we can restore [...ku-i-e-e]š as in KBo 20.73+ IV 8 (but we cannot exclude other possibilities, for example we read HUL-u-e-eš ši-wa-an-nieš in KUB 9.34 III 45). 
13 pa-ra- ${ }^{\top} a^{\top}$ ap-pa-an-zi ...

«They turn around it (i.e. the donkey) three times, but the fourth time they touch? ${ }^{14}$ it».

Even if the actions described in the second text are performed after reciting the formula, the two passages are clearly almost identical and we can restore KUB 35.146 III 5'-7' with a slight adjustment of the number of times they turn around the animal:

5' [...]x-iz-zi na-an-kán a-ra-ah-za-an-da

6' [8-ŠU wa-ah-nu-wa-an-zi I-NA] 9 KASKAL ${ }^{N I}$-ma-kán pa-ra-a

7' [ap-pa-an-zi ... -m]a ki-iš-ša-an me-ma-i

At this point we can go one step further in the analysis of KUB 35.146 III and consider the beginning of the column, compared to KBo 20.73+ IV 1-4:

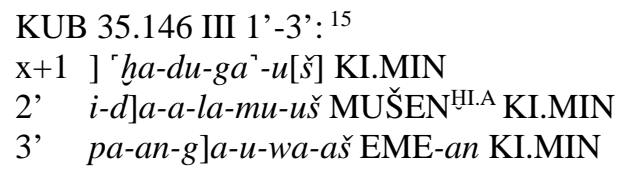

KUB 35.146 III 1'-3': 15

$\mathrm{x}+1$ ] 'ha-du-ga'-u[šc] KI.MIN

2' i-d]a-a-la-mu-uš MUŠEN ${ }^{\text {HI.A }}$ KI.MIN

3' pa-an-g]a-u-wa-aš EME-an KI.MIN

«[...] the terribl[e ...] ditto, $[\ldots$ the e]vil birds ditto, $[\ldots]$ the tongue (i.e. the slander) of the [mult]itude ditto».

KBo 20.73+ IV 1-4:

1 [ca. 4-5 signs $\check{S} U] M$-ŠU te-ez-zi ki-nu-na-wa-ra-at kar-a[p?- ...]

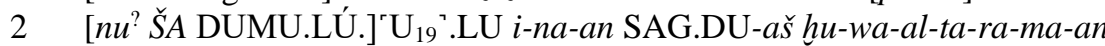

3 [ca. 2-3 signs -i]š-ke-mi ${ }^{16}$ tar-aš-ša-na-aš da-aš-ku-pí-ma-an KI.MIN IGI II.A-aš

4 [GEŠTU $\left.{ }^{\text {HI.A? }}-a\right]$ š $^{17}$ i-na-an KI.MIN hu-wa-*ar-na-pí-iš-ta-aš* a-ú-li-ya-aš i-na-an

KI.MIN

«[...] she (i.e. the "old woman”) says his (i.e. of the "lord of ritual”) [nam]e, (saying): "Now [...] it. The disease [of the hum]an being (and) the huwaltarama- of the head I am [...-]ing; the cawing of the throat ditto, the disease of the eyes (and) [of the ear]s ditto, the disease of the huwarnapišta- (and) of the carotid artery ditto"».

The two passages are clearly different, but they share a similar pattern: both of them list evils, and they do it in the same way, with the verb after the first element (not preserved in

\footnotetext{
For the meaning of parā epp- see CHD P, 118.

Starke 1985, 268-269.

Maybe [an-ni-i]š-ke-mi (cf. Haas 2003, 74 n. 384) or [hu-uk-ki-i]š-ke-mi.

17 Cf. HW' I, 630.
} 
KUB 35.146) and KI.MIN after the others. In both texts these evils must be eliminated through a substitute. ${ }^{18}$

We can add here two other passages, both from the ritual of the "old woman" Tunnawiya, which, as above-mentioned, has several parellels with KBo 20.73+:

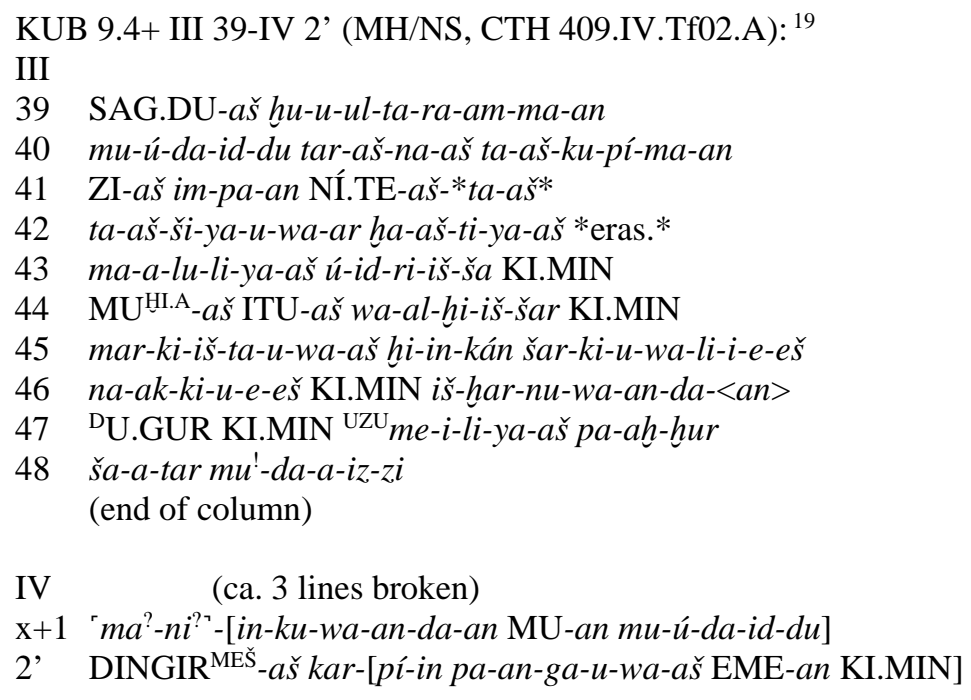

KUB 9.34 IV 1'-8' (MH/NS, CTH 409.II.Tf02.A): ${ }^{20}$

$\mathrm{x}+1$ [mar-ki-iš-da-u-wa-aš hi-in-ká]n ${ }^{\mathrm{D}} \mathrm{s} a r-k i-{ }^{-} u$-wa-li-ya-aš

2' [na-ak-ki-u-e-eš KI.MIN iš-har]-nu-wa-an-da-an DU.GUR KI.MIN

3' [ [نZU me-i-li-ya-aš pa-ah]-hur ša-a-tar mu-ta-iz-zi

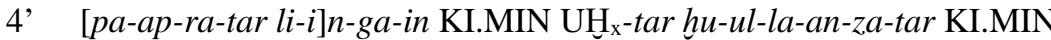

5' [... X-u-wa ha-a]n-da ${ }^{21}$ KI.MIN HUL-lu ha-du-ga-tar KI.MIN

6’ [HUL-mu-uš] Ù ${ }^{\mathrm{MES}}-u s ̌$ HUL-lu-uš MUŠEN ${ }^{\mathrm{HI}}$.A $-u s ̌$ KI.MIN

7' ma-ni-in-ku-wa-an-da-an MU-an mu-ta-id-du

8' $\quad$ DINGIR ${ }^{\mathrm{MEŠ}}$-aš kar-pí-in pa-an-ga-u-wa-aš EME-an KI.MIN

18 We do not have an explicit mention of this animal in KUB 35.146 and, despite the parallel, we cannot be sure it was a donkey. Nor can we say if this substitute was introduced for the first time in the broken beginning of 1. 5' or if it had been presented before.

19 Beckman 1990, 39-40.

20 Hutter 1988, 40. See also I 21'-30' and II 1-2 (Hutter 1988, 26-28, with the commentary at pp. 69-73).

21 Cf. HT 6+ I 9' (NS, CTH 409.IV.Tf05.A; Beckman 1990, 41). 
The two texts clearly run parallel and we can restore the lost beginning of KUB 9.4+ IV from KUB 9.34, so a single complete translation can be offered:

«It (i.e. the piglet of the god Pannunta) shall remove the hultaramma- of the head; the cawing of the throat, the burden of the soul, the oppression of the body and the widriš of bone and skin? ditto, the wounds of years (and) months ditto, the sudden death (and) the vengeful? nakkiu-demons ditto, bloodied U.GUR ditto; it will remove the fire (i.e. the fever) and the irritation? of the flesh?. The impurity and the perjury ditto, the sorcery and the conflict ditto, the [...] ditto, the evil fear ditto, the evil dreams (and) the evil birds (i.e. evil omens) ditto. It shall remove the short years; the anger of the gods (and) the tongue (i.e. the slander) of the multitude ditto».

All these elements (and others which are listed in the following lines in both texts) ${ }^{22}$ have to be removed using a substitute (here a piglet), such as the diseases in KBo 20.73+ and the evils in KUB 35.146. With these two texts we can somehow reduce the gap between KUB 35.146 and KBo 20.73+. The similarities between these lists are evident: KUB 9.4+ III 39-40 contains the same elements of KBo 20.73+ IV 2-4 (SAG.DU-aš huwaltarama- and tarašnaš taškupima-): ${ }^{23}$ the remaining diseases are different here (such as the verb used), but the beginning of the text enumerates almost the same evils of the parallel one, ${ }^{24}$ so in column IV we have probably a simplified list. On the other hand KUB 9.34 IV apparently shares 1l. 5'-8' with KUB 35.146 III 1'-3', which we could try to restore as follows:

$$
\begin{aligned}
& \mathrm{x}+1 \text { [... x-u-wa ha-an-da KI.MIN i-da-a-lu] 'ha-du-ga-tar }{ }^{25} \text { KI.MIN } \\
& \text { 2' [i-da-a-la-mu-uš Чับ }{ }^{\mathrm{MEŠs}}-u s ̌ \text { i-d] } a-a-l a-m u-u s ̌ \text { MUŠEN }{ }^{\text {HI.A }} \mathrm{KI} \text {.MIN } \\
& \text { 3' } \quad\left[\ldots{ }^{26} \mathrm{DINGIR}^{\mathrm{MEŠ}}\right. \text {-aš kar-pí-in pa-an-g]a-u-wa-aš EME-an KI.MIN }
\end{aligned}
$$

This is obviously just an attempt: we cannot restore all the elements in KUB 9.34 IV 5'8' due to space, but it seems clear that the two sections are parallel and unfortunately we don't know how and how long the list of evils before this preserved part was. Surely in KUB 35.146 we don't have the other evil things which follow "the tongue of the multitude" in the parallel texts, since l. 4' ends with the verb irhāizzi and it could possibly be restored as [nu $12{ }^{\text {UZU ÚR }}{ }^{\text {HI.A }}$ QA-TAM-MA-pát] ir-ha-a-iz-zi: «[she (i.e. the "old woman") likewise] enumerates [the twelve body parts]» (cf. KUB 9.4+ II 24, 28-29, 37 and KUB 9.34 III 8', $\left.12^{\prime}, 18^{\prime}-19^{\prime}\right)$, but I admit this is highly speculative.

22 According to Beckman (1990, 52), in both texts the following paragraphs contained the specification of the expression "the tongue of the multitude", listing the "tongues" of several groups of persons.

23 These can be found also in KUB 9.34 I 21'-22' (Hutter 1988, 26), with ahrama- instead of taškupima-.

24 Curiously, the only elements lacking in KBo 20.73+ I 9'-16' are those we can read at the beginning of KUB 35.146 III.

25 Contra Starke, who reads ${ }^{\top} h a-d u-g a^{\top}-u[\check{s}]$, I prefer this reading, which is supported by the parallel and follows the common Hittite word order for attributive adjectives. Furthermore, compare the traces of the sign, which show a small vertical wedge, with the sign TAR in II 14'.

26 Definitely no space for something like ma-ni-in-ku-wa-an-da-an MU-an KI.MIN, so we must think that this is lacking here. Cf. also KUB 12.58+ II 35-39 (MH/NS, Ritual of Tunnawiya, CTH 409.I.A; Götze 1938, 1214). 
So, at last we have partly restored - with a fair degree of likelihood - the column III of this small ritual fragment, showing that the analogy with the rituals of Tunnawiya, recognised by Emmanuel Laroche according to the obverse, is confirmed by the reverse. Clearly, we cannot be sure that this ritual didn't belong to the group of rituals ascribed to Tunnawiya (such as in the case of KBo 20.73+), but what we can say is that different compositions, whether related to each other or not, share the same heritage of formulas. This leads us to the problem of how ritual texts were redacted.

Situations like the one presented in this paper are indeed common in Hittite literature, not only between texts of the same genre, but also between compositions of different nature. Giulia Torri has shown, for example, how much Hittite prayers and magical rituals have in common and she has presented several examples of texts of both genres, which display similar - if not identical - expressions. ${ }^{27}$ This surely could tell us something about the scribal practice and the use of the library collections in drafting new texts. As G. Torri says, «the prayers and the rituals, like many other texts, were copied and preserved in the libraries over the years because they corresponded to a significant heritage in the hand of the scribes for the creation of new compositions over and over again during the whole of Hittite history». ${ }^{28}$ As a matter of fact, concerning the magical rituals, Jared Miller ${ }^{29}$ has extensively and convincingly argued that, against the often claimed view according to which these compositions were transcribed through dictation or interviewing the ritual practioner, ${ }^{30}$ textual evidence rather suggests that «they were composed primarily by scribes exploiting the body of knowledge that they were able to recall from previous experience, at times also utilizing written sources», ${ }^{31}$ and, specifically concerning the rituals of Tunnawiya, J. Miller claims: «A scribe or scribes may have created the compositions from their own resources, including their personal experience as participants in or observers of such rites, as well as the archives to which they had access». ${ }^{32}$ These remarks could be extended to all the ritual texts composed by the scribes, but also to compositions of different genre. However, we obviously cannot exclude completely the dictation hypothesis. Concerning the Kizzuwatna rituals, for example, we must agree with

7 Torri 2003.

28 Torri 2003, 222.

29 Miller 2004, 469-532.

30 Cf. Haas 1994, 884 and Trémouille 2004, 180-181, 185, n. 153. This claim seemed to be confirmed by a passage in the ritual of the "old woman" Tunnawiya, in which the scribe seems to ask a question to the ritual practioner; KUB 12.58+ I 39-42 (MH/NS, CTH 409.I.A; Götze 1938, 8): ku-e-et-ma-an-ma MUNUS־ŠU'.GI kee da-aš-ke-ez-zi EGIR-an-ma-aš-ša-an / I I-i pé-ra-an GIŠZZA.LAM.GAR ${ }^{\mathrm{HI} . \mathrm{A}}$ ŠA GI ka-ru-ú i-ya-an-ta i-ya-anzi-ma / ku-wa-pí nu ku-wa-pí har-ša-u-wa-ar ma-ni-in-ku-wa-an NU.GÁL / [GIšAPI]N Ú-UL a-ra-an-za nu GIŠZA.LAM.GAR a-pí-ya i-ya-an-za: «But while the "old woman” is getting these (things), in (her) absence beside the river a tent of reeds (has) already (been) made. Now where do they make (it)? - where there is no cultivation near by, (and) [the plou]gh (does) not come, there the tent is made». This is the translation according to Götze 1938, 9, but, as Miller (2004, 481-482) suggests, there are no compelling elements, which force to interpret the sentence as a question and the passage could be translated as follows: «But while the old woman is getting these (things) - reed huts, however, have already been made before the river. Where(ever) they make (it), though, the hut is made there where no cultivation is nearby (and) the plough does not come» (Miller 2004, 482).

31 Miller 2004, 476. See also Christiansen 2006, 22-30, who arrives at similar conclusions.

32 Miller 2004, 522. 
Craig Melchert ${ }^{33}$ and Ilya Yakubovich ${ }^{34}$ on considering the correct grammar of the Kizzuwatna Luwian passages in these rituals as a strong evidence of dictation by Luwian speakers, but obviously we cannot say which one was the "original” dictated copy and which ones were the reworked versions. Concurrently, we can also assume, as Rita Francia has pointed out, ${ }^{35}$ that even when a composition was dictated there was some degree of editorial work: scribes probably wrote first a draft through dictaction, and then they realized the final version, dividing the text into paragraphs and adding the introduction and the colophon. However, once these texts were copied and stored in the library collections, they were available for reuse by the scribes, who could take patterns, passages, similes, etc. from them and redact a new composition for another circumstance, possibly according to general indications from a ritual practioner.

This is a very interesting field of study and we wish that the discovery of new materials and a deeper investigation in the existing ones could provide new hints for a clearer understanding of the composition of ritual texts and of the scribal work in general.

\title{
APPENDIX
}

In conclusion, I present here a new edition of KUB 35.146, restored according to the parallels cited in this paper:

\author{
KUB 35.146 (767/c) \\ Ro II \\ $\mathrm{x}+1$ [ca. 10-11 signs ki-iš-ta-nu-] 'nu-un \\ 2' [...ki-i]š-ta-nu-nu-un
}
3' [ca. 8 signs pa-a]n- $g a{ }^{\top}-u-w a-a s ̌ ~ h u-u s ̌-s ̌ i-i-' i l '$
4' [ca. 6 signs EGIR-an-d]a-ma-kán pa-an-ga-u-wa-aš
5, $\left[\mathrm{EME}-a n^{\text {? }} . .{ }^{36}\right] k i-i s ̌-t a-n u-n u-u n^{37}$

\section{6' [nu-za? MUNUS ŠU.GI? G $]^{\mathrm{I}}$ pát-tar da-a-i na-aš-ta pád-da-ni kat-ta \\ 7' [ca. 2-3 signs $\left.{ }^{38} z i-n a-a k-k\right] i{ }^{\text {NINDA } n i-n i-y a-m i-i s ̌ ~}{ }^{\text {NINDA } h a r-n a-a n-t a-a s ̌-s ̌ i-i s ̌ ~}$ \\ 8' [GIŠHAŠHUR ku-un-k]u-ma-a-an GIŠPĚŠ ha-aš-ta-i wa-al-li-in-za}

3 Melchert 2013, 169-170.

4 Yakubovich 2010, 280.

35 Francia 2013, 21.

36 There could be nothing after the first word in the break, since there is a large blank space before the verb.

37 For ll. 1'-5' cf. KUB 17.15+ II 1'-20', III 1'-5' (NS, CTH 767.2.C; Starke 1985, 232-233).

38 The restoration of this line is quite problematic: since the first element in the next paragraph is the zinakki, we can surely restore it, but there is still space in the break. Parallels suggest a verb, see for example KUB 12.58+ I 51 (MH/NS, Ritual of Tunnawiya, CTH 409.I.A; Götze 1938, 8): nu-ǔ̌-ša-an ki-i h̆u-u-ma-an ${ }^{\mathrm{GI}}$ pád-da-ni-i kat-ta ha-an-da-[i]z-zi: «All these things she (i.e. the "old woman”) arranges in a basket». Elsewhere we have similar expressions with the verbs šuhha-, išhuwai- or dai- (see CHD P, 241-242 and HED PA, 202-205 for examples), but here the space remaining after restoring $z i-n a-a k-k] i$ is very few and probably only $d a-a-i$ would fit. Furthermore, an object would be needed for this verb (at least $k e-e$ ), but this is lacking here. 
9' [ca. 4-5 signs ]x ${ }^{39}$ nu-uš-ši-kán GI pát-tar še-er ar-ha

10' [wa-ah-nu-uš-] ${ }^{\ulcorner} k{ }^{\top}-e z-z i$ hu-uk-ki-iš-ke-ez-zi-ma ki-iš-ša-an

11' $\overline{\text { [ca. } 3 \text { signs ]x ku-i-e-eš ú-wa-an-zi nu-za zi-na-ak-ki da-an-du }}$

12' [ca. 1-2 signs -]an-zi-ma-an ku-i-e-eš nu-za ${ }^{\mathrm{NINDA}}$ ni-ni-ya-mi-in da-an-du

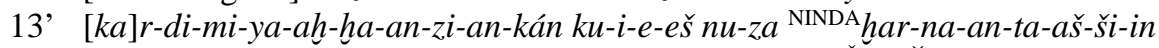

14' [d]a-an-du pa-aš-tar-nu-wa-an-zi-an ku-i-e-eš nu-za GIš HुAŠHUR

15' [d]a-an-du ku-mar-nu-wa-an-zi-an ku-i-e-eš nu-za ku-un-ku-ma-a-an

16’ [da-a]n-du la-ah-la-ah-h̆i-nu-uš-ke-er-*ra-an-kán eras.* ku-i-e-eš

17’ [nu-za $\left.{ }^{\mathrm{GI}}\right]^{\mathrm{S} r} \mathrm{PE} \mathrm{S}^{\urcorner} d a-a n-d u$

18' [ca. 3 signs ku-] 'i’-e-eš i-ya-an-ta-ri nu-za ha-aš-ta-i

19' [da-an-du ca. 2 signs -l]i-in-ti ${ }^{40} k u-i-e-e s ̌ ~ n u-z a ~ w a-a l-l i-i n$

20' [da-an-du al-wa-an-z]é-ni-ma-kán an-tu-uh-ši

21' [ke-e? IŠ-TU? GI pád-d]a-'na'-az ${ }^{41}$ hu-it-ti-ya-nu-un

$22^{\prime} \quad[\ldots] \times \mathrm{x} \times[\ldots-]^{\ulcorner} z i^{\top}$

Vo III

$\mathrm{x}+1$ [ca. 2 signs -u-wa ha-an-da KI.MIN i-da-a-lu] 'ha-du-ga-tar' KI.MIN

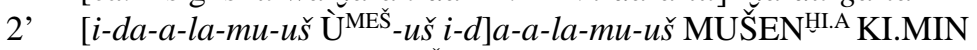

3' [ca. 1-2 signs DINGIR ${ }^{\mathrm{MES}}$-aš kar-pí-in pa-an-g]a-u-wa-aš EME-an KI.MIN

4' [nu 12 UZU ÚR ${ }^{\text {HI.A }}$ QA-TAM-MA-pát] ir-h̆a-a-iz-zi

5' [ca. 10 signs ]x-iz-zi na-an-kán a-ra-ah-za-an-da

6' [8-ŠU wa-ah-nu-wa-an-zi I-NA] 9 KASKAL ${ }^{N I}$-ma-kán pa-ra-a

7’ [ap-pa-an-zi ca. 5 signs - $m] a$ ki-iš-ša-an me-ma-i

8' [ca. 6-7 signs ku-i-e-e]š ši-wa-an-ni-e-eš

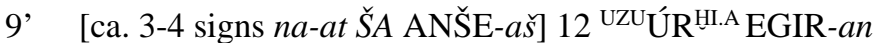

10’ [pa-a-an-du nu e-eš-h̆ar ak-k]u-uš-kán-du UZÙ̀.UDU-ma-wa

11' [a-az-za-ku-wa-an-du UZUSA-ma tú] $h$-ša-an-ni-an-du

12' [ha-aš-ta-i-ma du-wa-ar-ni-]iš-kán-du nam-ma-an

13' [ca. 9-10 signs ]x wa-al-ha-an-zi

39 We probably need a verb here, since the wallin is the last element cited in the formula below. We can see only traces of a vertical wedge after the break, so we may think about a participle, for example $i \check{s}$ - $h u-u$-wa-a]n or the like. Possibly, also kitta or kittari would fit.

40 This should be a Luwian verb.

41 It is quite likely that the text contained here at least $\left[\ldots{ }^{\mathrm{GI}}\right.$ pád-d] $a^{-}{ }^{-} n a{ }^{\top}-a z$, which fits well in this paragraph: we can suppose that the ritual practioner, after putting all the materia magica in the basket, began to take out each substance while reciting the conjuring formula. 
14' [ca. 11-12 signs ]x-wa-ra-at kar-aš-ke-mi

15' [ca. 11-12 signs -š]i?-iš-ke-mi

16' [ca. 11-12 signs (-)]ú-i-ta-ú

17' [ca. 12-13 signs -r]i-iš-ke-du

18' [ca. 12-13 signs ]x tu-ra-ad-du

19' [ca. 12-13 signs ]x-la-a-ad-du

20, [...--a]d-du

$21, \quad[\ldots] \times \times \times$ x $[\ldots] \times \times x$

\section{TRANSLATION}

Ro II

$\mathrm{x}+1$ [“... I have extingui]shed

2' [... I have ex]tinguished

3' [...] the huššl $l^{42}$ of the [mul]titude

4' [...] but [the]n [the tongue?

5 ' of the multitude [...] I have extinguished"

6' [And? the "old woman"?] takes/places a basket and down in the basket

7' $\quad[\ldots$ a zinakk $] i^{-}{ }^{43}$, a spiral-shaped bread ${ }^{44}$, a leavened bread ${ }^{45}$,

8' [an apple, a kunk]um $\bar{a}$-fruit ${ }^{46}$, a fig, a bone, a thigh ${ }^{47}$

9' [...], and over (and) away from him the basket

10' [she keeps wav]ing and she keeps conjuring as follows:

11' [“...] those who come shall take the zinakki-,

42 No assured connection with huššil(i), huššelli-, huššulli- 'clay pit, dump' and uncertain Luwian status (cf. Rieken 1996, 293, Rieken 1999, 438 and CLL, 77). See also HED H, 409 ('public dump?').

43 For this substance, perhaps a fruit, see Haas 2003, 359. The zinakki- also appears in the ritual of Tunnawiya, in a list which is partly parallel to the one in KUB 35.146: $\mathrm{TI}_{8}{ }^{\mathrm{MUŠEN}}$-aš pát-tar ha-aš-ta-i te-pu w[a]-al-li-in te'pu' / [...] iš-ša-'ra'-ši-la-aš NUMUN-an Gišs $\mathrm{PÈS}$ 'te'-pu zi-na-ak-ki-išs / [te-pu ...]: «An eagle’s wing, bone, a small quantity, thigh, a small quantity, [...] a seed of ǐšarašila-plant, figs, a small quantity, zinakki-, [a small quantity ... ]» (KUB 12.58+ I 46-48; Götze 1938, 8). With Haas 2003, 129-130 (with n. 565) and contra Götze and CLL, 10, I read here w[a]-al-li-in (not :al-li-in, with the Glossenkeil); so we find the same sequence of KUB 35.146 II 8': ha-aš-ta-i wa-al-li-in-za.

44 Cf. CLL, 158; Hoffner 1974, 174-175.

45 Cf. Hoffner 1974, 155-156.

46 Or a vegetable, perhaps the 'cucumber' (cf. HED K, 250-251; Haas 2003, 354).

47 Since there is a bone before, it is likely that Luw. wallin is the same as Hitt. ${ }^{\text {Uzu }}$ walla-. Contra CLL, 251, I take wallin as a neuter stem and wallinza in l. 8' as a nom.-acc. sg. with the particle /-sa/ (-za after /n/ and /1/). See also Haas 2003, 129, who considers the haštai and the wallinza here as the 'core' and the 'flesh' of the fruit, respectively. 
12' those who [...] him shall take the spiral-shaped bread?,

13' those who make him [an]gry shall [t]ake

14' the leavened bread, those who spurn ${ }^{48}$ him shall [t]ake

15 ' the apple, those who aggravate ${ }^{49}$ him shall [ta]ke

16' the kunkumā-fruit (and) those who kept perturbing him

17' shall take the fig.

18, [... those w] ho go [shall take]

19' the bone, those who [...] [shall take]

20' the thigh and for the [sor]cerer

21' I have pulled out [these things?] from the [bas]ket”.

22’ traces

Vo III

$\mathrm{x}+1$ [the ... ditto, the evil] fea[r] ditto,

2' [the evil dreams (and) the e]vil birds (i.e. evil omens) ditto,

3' [... the anger of gods] (and) the "tongue" (i.e the slander) of the [mult]itude ditto;

4' [and just in the same way] she enumerates [the twelve body parts],

5' [she ...] and [they turn] around it (i.e. the donkey)

6' [eight times], but the ninth time

7' [they touch? (it)....] she recites as follows:

8' [“... those whic]h are of divine origin

9' [... and they shall go] behind the twelve body parts

10' [of the donkey!] They shall keep [drin]king [the blood (of the donkey)], (its) fat

11' [they shall keep eating, (its) sinew] they shall keep [c]utting off

12' [and (its) bone] they shall keep [brea]king!” Then [they ...] it,

13, [...] they strike.

14' [“...] I'm cutting it,

15 ' [...] I'm [...-]ing

$16, \quad[\ldots] \ldots$

17 , [...] it? shall keep [...-]ing

18 ' [...] it? shall ...!

19 ' [...] it? shall [...]!

20' [...] it? shall [...]!”

21’ traces

48 For the verb (:)paštar(iya)- cf. CHD P, 210-211 and HED PA, 193.

49 Translation according to HED PA, 193. 


\section{REFERENCES}

BECKMAN, G.M.

1990 The Hittite "Ritual of the Ox” (CTH 760.I.2-3): Orientalia. Nova Series 59/1 (1990), pp. 34-55.

ChristiANSEN, B.

2006 Die Ritualtradition der Ambazzi. Eine philologische Bearbeitung und entstehungsgeschichtliche Analyse der Ritualtexte CTH 391, CTH 429 und CTH 463 (Studien zu den Boğazköy-Texten 48), Wiesbaden 2006.

GÖTZE, A

1938 The Hittite Ritual of Tunnawi (American Oriental Series 14), New Haven 1938.

HAAS, V.

1994 Geschichte der hethitischen Religion (Handbuch der Orientalistik I/15), Leiden - New York - Köln 1994.

2003 Materia Magica et Medica Hethitica. Ein Beitrag zur Heilkunde im Alten Orient, 2 vols., Berlin - New York 2003

HOFFNER, H.A.

1974 Alimenta Hethaeorum. Food Production in Hittite Asia Minor (American Oriental Series 55), New Haven 1974.

HUTTER, M.

1988 Behexung, Entsühnung und Heilung. Das Ritual der Tunnawiya für ein Königspaar aus mittelhethitischer Zeit (KBo XXI 1 - KUB IX 34 - KBo XXI 6) (Orbis Biblicus et Orientalis 82), Göttingen 1988.

FRANCIA, R.

2013 Gli scongiuri e le historiolae nella letteratura magica ittita, PhD Diss. Sapienza Università di Roma, Roma 2013.

FUSCAGNI, F.

2013 Fragment eines Beschwörungsrituals mit mythologisch-erzählenden Partien (CTH 458.1), 2013.

LAROCHE, E.

1954 Review of H. OTTEN, Keilschrifturkunden aus Boghazköi 35. Luvische und Palāische Texte (KUB 35), Berlin 1953; H. OTTEN, Luvische Texte in Umschrift (Institut für Orientforschung, Veröffentlichung 17), Berlin 1953; H. OTтEN, Zur grammatikalischen und lexikalischen Bestimmung des Luvischen. Untersuchung der luvili-Texte (Institut für Orientforschung, Veröffentlichung 19), Berlin 1953, Bibliotheca Orientalis 11 (1954), pp. 121-124.

MELCHERT, H.C.

2013 Luvian Language in "Luvian” Rituals in Hattuša: B.J. ColLins - P. MichALOwSKi (eds.), Beyond Hatti. A Tribute to Gary Beckman, Atlanta 2013, pp. 159-172.

MiLLER, J.L.

2004 Studies in the Origins, Development and Interpretation of the Kizzuwatna Rituals (Studien zu den Boğazköy-Texten 46), Wiesbaden 2004.

RIEKEN, E.

1996 Beiträge zur anatolischen Sprachgeschichte, Altorientalische Forschungen 23/2 (1996), pp. 289-297.

1999 Untersuchungen zur nominalen Stammbildung des Hethitischen (Studien zu den Boğazköy-Texten 44), Wiesbaden 1999. 
XIX (2015) Parallel passages among Hittite-Luwian rituals: for the restoration of KUB 35.146

STARKE, F.

1985 Die keilschrift-luwischen Texte in Umschrift (Studien zu den Boğazköy-Texten 30), Wiesbaden 1985.

TORRI, G.

2003 Common Literary Patterns in Hittite Magical Rituals and Prayers: Orientalia. Nova Series 72/2 (2003), pp. 216-222.

TRÉMOUILLE, M.-C.

2004 I rituali magici ittiti: Res Antiquae 1 (2004), pp. 157-203.

YAKUBOVICH, I.S.

2010 Sociolinguistics of the Luvian Language (Brill's Studies in Indoeuropean Languages and Linguistics 2), Leiden 2010. 


\section{SOMMARIO}

DipartimENTo SCIENZE DELl'ANTICHITÀ

SEZIONE di ORIENTALISTICA

\section{VICINO ORIENTE \\ XIX - 2015}

L. Nigro - Bethlehem in the Bronze and lron Ages
in the light of recent discoveries by the Palestinian MOTA-DACH

$\checkmark$. Pisaniello - Parallel passages among Hittite-Luwian rituals:

for the restoration of $K U B 35.146$

F. Spagnoli - Una testa di sileno in bronzo da Mozia

N. Chiaren

dall Area sacra del Kothon a Mozia

G. Labisi - al-Fudayn: an Umayyad residence in Northern Jordan

P. Buzi - Early Christianity in the Fayyūm: the new contribution of archaeology

I. Materia - Preliminary notes on the ware depicted on the ceiling

of the Cappella Palatina in Palermo

S. Autiero - Indian Ocean trade:

a reassessment of the pottery find
$\left(3^{\text {rd }}\right.$ century $B C-S^{S^{t h}}$ century $\left.A D\right)$

M.M. Jamhawi - N. Al-Shakarchi - I. Al-Hashimi

Assessment of tourists' satisfaction in the downtown of Amman

SCAVI E RICERCHE

L. Nigro - C. Fiaccavento - M. Jaradat - J. Yasine

A

L. Nigro - D. Montanari - M. Ghayyada - J. Yasine

A Middle Bronze and Iron Age necropolis near Bethlehem (Palestine)

L. Nigro - G. Ripepi - I. Hamdan - J. Yasine

15 Interim Report

and valorization of archaeological heritage

R. Francia - L'archivio di tavolette del complesso B-C-H di Büyükkale

organizazione degli archivi reali ittiti. Considerazioni preliminari

V. Pisaniello - La collezione di tavolette del complesso B-C-H di Büyükkale

T. De Vincenzi - L'archivio di tavolette del complesso B-C-H
sull'acropoli di Büyükkale

Museo del Vicino Oriente, Egitto e Mediterraneo

L. Nigro - Il nuovo allestimento del Museo del Vicino Oriente,

Egitto e Mediterraneo della Sapienza

D. Montanari - Bollettino delle attività del Museo del Vicino Oriente,

Egito e Meditraneo della Sapienza, anno 2015

RECENSIONI

A. Orsingher - E. PAPPA (2013), Early Iron Age Exchange in the West:

(Ancient Near Eastern Studies Supplement Series 43)

Leuven - Paris - Walpole 2013, MA.: Peeters $\frac{1}{2}$

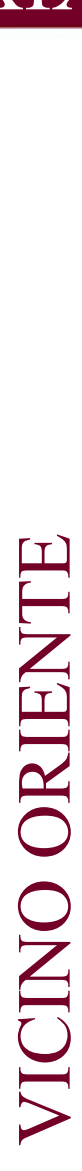

345

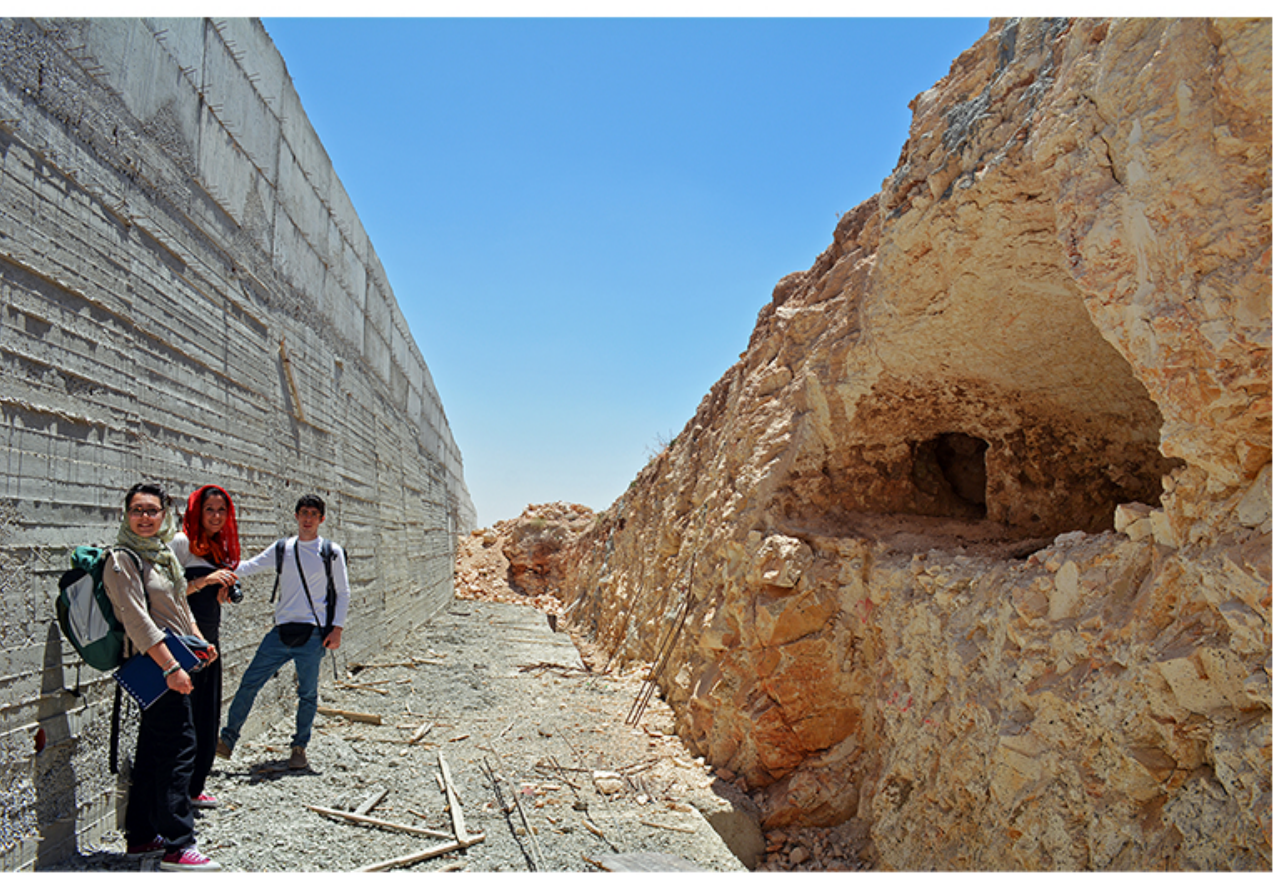

ROMA 2015 


\section{VICINO ORIENTE XIX - 2015}


VICINO ORIENTE

SAPIENZA UNIVERSITÀ DI ROMA

DIPARTIMENTO SCIENZE DELL'ANTICHITÀ

SEZIONE DI ORIENTALISTICA

Scientific Editor: Lorenzo Nigro

International Scientific Committee: Brian Rose, Frank Braemer, Mounir Fantar, Piero Bartoloni, Thomas Schaefer, Zeidan Kafafi

National Scientific Committee: Carlo Giovanni Cereti, Maria Vittoria Fontana, Sebastiano Tusa, Massimiliano Marazzi

Editorial Board: Daria Montanari, Chiara Fiaccavento

Tipografia: SK7 - Roma

ISSN 0393-0300

Rivista con comitato di referee

Journal with international referee system

www.lasapienzatojericho.it/SitoRivista/Journal/Rivista.php

In copertina: Tomba B9, necropoli di Khalet al-Jam’a (Betlemme). 
VICINO ORIENTE

SAPIENZA UNIVERSITÀ DI ROMA

DIPARTIMENTO SCIENZE DELL'ANTICHITÀ

SEZIONE DI ORIENTALISTICA

\section{SOMMARIO}

ARTICOLI

L. Nigro - Bethlehem in the Bronze and Iron Ages

in the light of recent discoveries by the Palestinian MOTA-DACH

V. Pisaniello - Parallel passages among Hittite-Luwian rituals:

for the restoration of KUB 35.146

F. Spagnoli - Una testa di sileno in bronzo da Mozia

N. Chiarenza - Una matrice per terrecotte con sileno dall'Area sacra del Kothon a Mozia

G. Labisi - al-Fudayn: an Umayyad residence in Northern Jordan

P. Buzi - Early Christianity in the Fayyūm: the new contribution of archaeology

I. Materia - Preliminary notes on the ware depicted on the ceiling

of the Cappella Palatina in Palermo

S. Autiero - Indian Ocean trade:

a reassessment of the pottery finds from a multidisciplinary point of view ( $3^{\text {rd }}$ century $B C-5^{\text {th }}$ century $\left.A D\right)$

M.M. Jamhawi - N. Al-Shakarchi - I. Al-Hashimi

Assessment of tourists' satisfaction in the downtown of Amman

SCAVI E RICERCHE

L. Nigro - C. Fiaccavento - M. Jaradat - J. Yasine Archaeology from A to Z: Abu Zarad, an ancient town in the heartland of Palestine

L. Nigro - D. Montanari - M. Ghayyada - J. Yasine

Khalet al-Jam'a. A Middle Bronze and Iron Age necropolis near Bethlehem (Palestine) 185 
VICINO ORIENTE

SAPIENZA UNIVERSITÀ DI ROMA

DIPARTIMENTO SCIENZE DELL'ANTICHITÀ

SEZIONE DI ORIENTALISTICA

L. Nigro - G. Ripepi - I. Hamdan - J. Yasine

The Jericho Oasis Archaeological Park - 2015 Interim Report.

Italian-Palestinian Cooperation for protection

and valorization of archaeological heritage

R. Francia - L'archivio di tavolette del complesso B-C-H di Büyükkale

e l'organizzazione degli archivi reali ittiti. Considerazioni preliminari

V. Pisaniello - La collezione di tavolette del complesso B-C-H di Büyükkale

T. De Vincenzi - L'archivio di tavolette del complesso B-C-H sull'acropoli di Büyükkale

Museo del Vicino ORIente, Egitto e MediterRaneo

L. Nigro - Il nuovo allestimento del Museo del Vicino Oriente,

Egitto e Mediterraneo della Sapienza

D. Montanari - Bollettino delle attività del Museo del Vicino Oriente,

Egitto e Mediterraneo della Sapienza, anno 2015

\section{RECENSIONI}

A. Orsingher - E. PAPPA (2013), Early Iron Age Exchange in the West:

Phoenicians in the Mediterranean and the Atlantic

(Ancient Near Eastern Studies Supplement Series 43),

Leuven - Paris - Walpole 2013, MA.: Peeters 